\title{
Russula pyriodora, a new fragrant species described from Finland.
}

\author{
JUHANI RUOTSALAINEN and SEPPO HUHTINEN
}

\begin{abstract}
RUOTSALAINEN, J. \& HUHTINEN, S. 2011: Russula pyriodora, a new fragrant species described from Finland. - Karstenia 51: 23-30. Helsinki. ISSN 0453-3402.

A new species, Russula pyriodora, is described based on Finnish material. It is characterized by an appearance of $R$. betularum, but has a distinctive odour of pears. Other differentiating features, both macroscopical and microscopical, are also discussed. The new species is also compared with the type of $R$. alborosea, which is a likely synonym of $R$. mairei.
\end{abstract}

Key words: Russulaceae, Russula, Atropurpurea, Russula pyriodora, Finland, taxonomy

Juhani Ruotsalainen, Metsätie 12 A 4, FI-71310 Vehmersalmi, Finland; e-mail: juhani. ruotsalainen@pp.inet.fi

Seppo Huhtinen, Herbarium, University of Turku, FI-20014 Turku, Finland; e-mail: seppo.huhtinen@utu.fi

\section{Introduction}

New taxa of the genus Russula Pers. are encountered in Finland every year. In most cases these new finds consist of only a few fruitbodies. Furthermore, it is often very laborious to find a second collection, even from the existing, plentiful collections. Consequently, during the past decades the senior author has refrained from describing such finds as new species - not even when more or less convinced about their novelty. In such cases the great overall variability, typical for most species of Russula, would not be reported properly. In Finland we know many distinctive species, which are closely related to existing, well known species. Describing these is hindered by the lack of existing type specimens. Furthermore, many of the neo- and epitypifications by Sarnari $(1998,2005)$, based on Romagnesi's collections, should be checked for the possibility of mixed collections. It is not rare to find out that the neo- and epitypes selected from older collections have been mixed collections, even if only two to three fruitbodies are present. For example in the case of $R$. clavipes Vel., the neo- typification by Kärcher (1996) is based on two fruitbodies which are not conspecific. Selection of a type without actually carefully studying material is never advisable. For example, descriptions like those by Romagnesi based on "clear" type specimens, are of questionable value when it is realized that those "clear" type collections are mixtures of more than one taxon, e.g. $R$. amoenoides Romagn. and $R$. terenopus Romagn. Hence, comparisons based on literature only, have led to many misunderstandings.

Being aware of the situation mentioned above, descriptions of new species of Russula, based on only three collections from two sites in Finland, is seldom advisable. Even in the current clear cut case, where we feel confident enough about the new status of our finds, one could not ignore type studies. Reumaux et al. (1996) described $R$. alborosea Reumaux which he later combined as a variety of $R$. betularum Hora (Reumaux \& Moënne-Loccoz 2003). The colours in R. betularum are reminescent of those of $R$. pyriodora but microscopical features are clearly different. The microscopical features given by Reumaux et al. (1996) for both $R$. betularum and $R$. alborosea 
demanded type study of the latter species. In the extreme south-western part of Finland one can possibly find a taxon of a similar appearance to our new species, namely $R$. minutula Vel. But it seems that the new species is a well-characterized, by its odour. The clear odour of pears was verified by several mycologists for the whole material.

\section{Materials and methods}

The specimens were studied with Leitz Laborlux 10 and characters drawn using a drawing apparatus. Spores were observed and measured using $\times 1250$ magnification from preparations made from gills in Melzer's Reagent (MLZ), $\mathrm{Q}$-values were measured from a spore print. Elements of the cap cuticle were studied in water, Congo red (CR) and Carbol Fuchsin using $\times 600$ magnification. They are illustrated from preparations in CR.

\section{Russula pyriodora Ruots., sp. nova-}

Figs. 1, 2, 4

MycoBank no.: MB563454

\section{E speciebus aliis Russulorum odore pyri differt.}

Typus: Finland. Kainuu. Paltamo, Tololanmäki, Kylmänpuro Nature Protection Area, Grid $27^{\circ} \mathrm{E}$ 713875:355055, 21.VIII.2011 Mauri Lahti \& Juhani Ruotsalainen, JR.8415F (KUO - holotypus; TUR - isotypus).

The new species is a small, apparently rare, lookalike of Russula betularum, differing in the clear pear odour and slightly sharp taste. Cap 1.8-5.5 $\mathrm{cm}$ diam, pale pink or rose colour when young, silky glossy, convex, becoming more flattened and matt when older, with paler patches due to age and dryness, umbo small and darker, margin smooth when young, later moderately but clearly sulcate. Lamellae straight, seceding, moderately spaced when young, greyish white when fresh, becoming yellowish white when more dry, rather distant when older, greyish white, ochraceous grey-white when more dry, lamellulae scanty. Stem longer than the cap diameter, 4-6 $\times 0.6-$ $1.3(-1.8) \mathrm{cm}$, at first cylindrical to slightly clavate, later widest in the middle, widening also at apex, greyish white or with a red hue, sometimes more clearly rosy red for the whole length, surface not totally smooth when old, tapering at the base especially when old. Context thin, fragile, greyish white, spongy in stem. Taste peculiarly unpleasant, oily and sweetish, slightly sharp in gills but not burning. Odour clear, sweet, pearlike, like that of Inocybe corydalina. Spore-print almost white, in Romagnesi's scale I.a(-b), in Dagron's scale 1(-2). Spores 8.2-9.6(-10.5) $\times$ (7-)7.2-7.8(-8.2) $\mu \mathrm{m}$, mean $9.0 \times 7.6 \mu \mathrm{m}$, mean $\mathrm{Q}=1.19$, broadly ellipsoid to obovate-ellipsoid; in a squash mount the ornamentation is variable, with warts, groups of warts or short crests, with hardly any connectives, warts mostly rounded, pointed warts rare; in a spore-print, spores are larger and warts are more spaced, pointed warts rare, up to $1.0 \mu \mathrm{m}$ high; plage small, partially amyloid with tiny warts or often only surrounded by a weakly amyloid zone. Basidia 34-36 × 10-12 $\mu \mathrm{m}$, four-spored, short, clavate. Cheilocystidia ca $85 \times 8.5-10.0 \mu \mathrm{m}$, abundant, fusiform with a long, tapering apex, often with a small appendix, contents bright or minutely granulose (in MLZ). Cuticle (in CR) with abundant dermatocystidia, either in small bunches (in Kainuu collections) and narrowly clavate, $6-8 \mu \mathrm{m}$ wide, $0-2$-septate, exceptionally non-variable; or (in Nilsiä collection) scattered, longer, almost cylindrical - narrowly clavate, rather non-variable. Epicutis hyphae narrow, 2.0-2.8 $\mu \mathrm{m}$ diam, cylindrical, the broadest narrowly clavate, septal intervals relatively long, contents not granulose.

\section{Ecology and distribution}

Russula pyriodora has so far been found from two sites in Finland. Both Paltamo (Kainuu) and Nilsiä (Pohjois-Savo), collection sites were nutrient-rich brook ravines with some influence of limestone. The holotype originates from a wet, wooded mire with a mosaic of tussocks of grasses and herb-rich areas. The main tree genus is Betula, together with Alnus, Salix and Picea (Fig. 3). In Nilsiä the site is dominated with large spruces, together with Betula, Alnus and Salix. It is hard to be sure about the host tree species; most likely it is Betula. On the other hand, the senior author has collected $R$. betularum from Betula-free plantations of spruce. However, these sites have not been as moist and nutrient rich as those where $R$. pyriodora has been found. Demanding species of fungi found nearby include Russula atroglauca Einhell., $R$. cremeoavellanea Singer, $R$. nauseosa 
(Pers.) Fr., R. olivina Ruots. \& Vauras, Inocybe maculata Boud. and Lactarius olivinus Kytöv.

Paratypi: FINLAND. Pohjois-Savo. Nilsiä, Palokangas, Loutteispuro Nature Protection Area, Grid $27^{\circ}$ E 710282:355214, 09.IX.2010 Ruotsalainen, JR. 8291 (KUO). Kainuu. Paltamo, Tololanmäki, Kylmänpuro Nature Protection Area (= type locality), Grid $27^{\circ} \mathrm{E}$ 713875:355055, 16.VIII.2010 Ruotsalainen, JR.8128F (KUO).

Specimens studied for comparison: ( $R$. alborosea) FRANCE. Ardennes. Bois de Toges, 21.IX.1994 Reumaux R.63c (G, isotype). - (Russula betularum) FINLAND. Pohjois-Savo. Kuopio, Vehmersalmi, Kulhua, $\mathrm{N}$ of Suurjärvi, Grid $27^{\circ}$ E 69525:35511-2, 09.VIII.1989 Ruotsalainen, JR.1394F (KUO). - (R. mairei) SWEDEN. Småland. Färgaryd, Hyltebryg, Fagus forest, 17.IX.1987 Ruotsalainen JR. 757 (Herb. JR); Femsjö, SW side of Södra Färgen, Fagus forest, 17.IX.1987 Ruotsalainen JR.763F (Herb. JR). ITALY. Veneto. Belluno, Trichiana, Col di Pera, Fagus forest, 20.VII.2001 Alpago-Novello, Vauras \& Ruotsalainen, JR.5702 (Herb. JR); Melere, Ongia, Fagus forest, 30.IX.2002 Ruotsalainen JR.6189 (Herb. JR); Limana, Valmorel, 27.VII.2006 Alpago-Novello, Vauras \& Ruotsalainen, JR.7558 (Herb. JR).

\section{Results and discussion}

In its present known distribution area, $R$. pyriodora has only one similar looking species, namely $R$. betularum. They are in the same size group and their overall pileus colouring is almost identical. The whiter gills and lack of red hues on the stem in $R$. betularum are good field characters. Russula pyriodora often has either red colouring or at least red hues on the stem. When fresh fruitbodies are available, taste and odour are also clear separating features, because $R$. betularum has a clearly sharper taste and a very weak, fruity odour. Microscopical features also differ. The new species does not have spores with the strong, well developed network so characteristic of $R$. betularum. The dermatocystidia also bear differences; in $R$. betularum they are more variable ranging from shorter to broader and longer/ narrower and they also are apically irregular in outline (Fig. 5).

Russula minutula has recently been discovered in southwestern Finland. It is a similarlooking, very rare mild species with white spore-print, which has only been found under broad-leaved trees in Ruissalo, Turku town. It belongs to subsection Roseinae due to the incrusted cuticular hyphae. Judging from the de- scription and illustrated spores, R. alborosea also needed to be taken into account (Reumaux et al. 1996: 69, 74, 105, 122, 281). It has been collected under Fagus but the description seems to point to $R$. betularum. A study of the isotype revealed spores which are different from those of $R$. pyriodora but which, on the other hand, do not match those illustrated by Reumaux et al. (1996: 105) as part of the diagnosis. As the spores reminded the senior author about $R$. mairei Sing., the microscopical features of the type of $R$. alborosea re-examined by the senior author are given below (cf. also Fig. 6). Spores measured 7.8-9.0 $\times 6.0-6.8 \mu \mathrm{m}$ and were mostly shortly ellipsoid with a small, slightly amyloid plage. Possibly many of the spores in the type are not fully mature because the biggest spores have a thinner reticulum compared to that of the smaller, more clearly amyloid spores, that also had larger warts. Compared to our material of $R$. mairei, these smaller and darker spores (more mature) were identical. Since Fagus is not native to Finland, we unfortunately still have too scanty knowledge on the variability of $R$. mairei. The original diagnosis of $R$. betularum (Hora 1960) suggests that Reumaux et al. (1996) had a deviating view of $R$. betularum sensu auct. Hence, we consider $R$. alborosea as a synonym of $R$. mairei.

The classification below generic level in Russula varies greatly between different authors (e.g. Romagnesi 1967, Sarnari 1998). Because $R$. pyriodora and $R$. betularum are macroscopically close, small, white-spored and more or less sharp species, they should be placed to the same group ("serie"). We follow Sarnari's idea of subsection Russula to which he created "serie" Atropurpurea, which seems to be the most logical placement for our new species. 

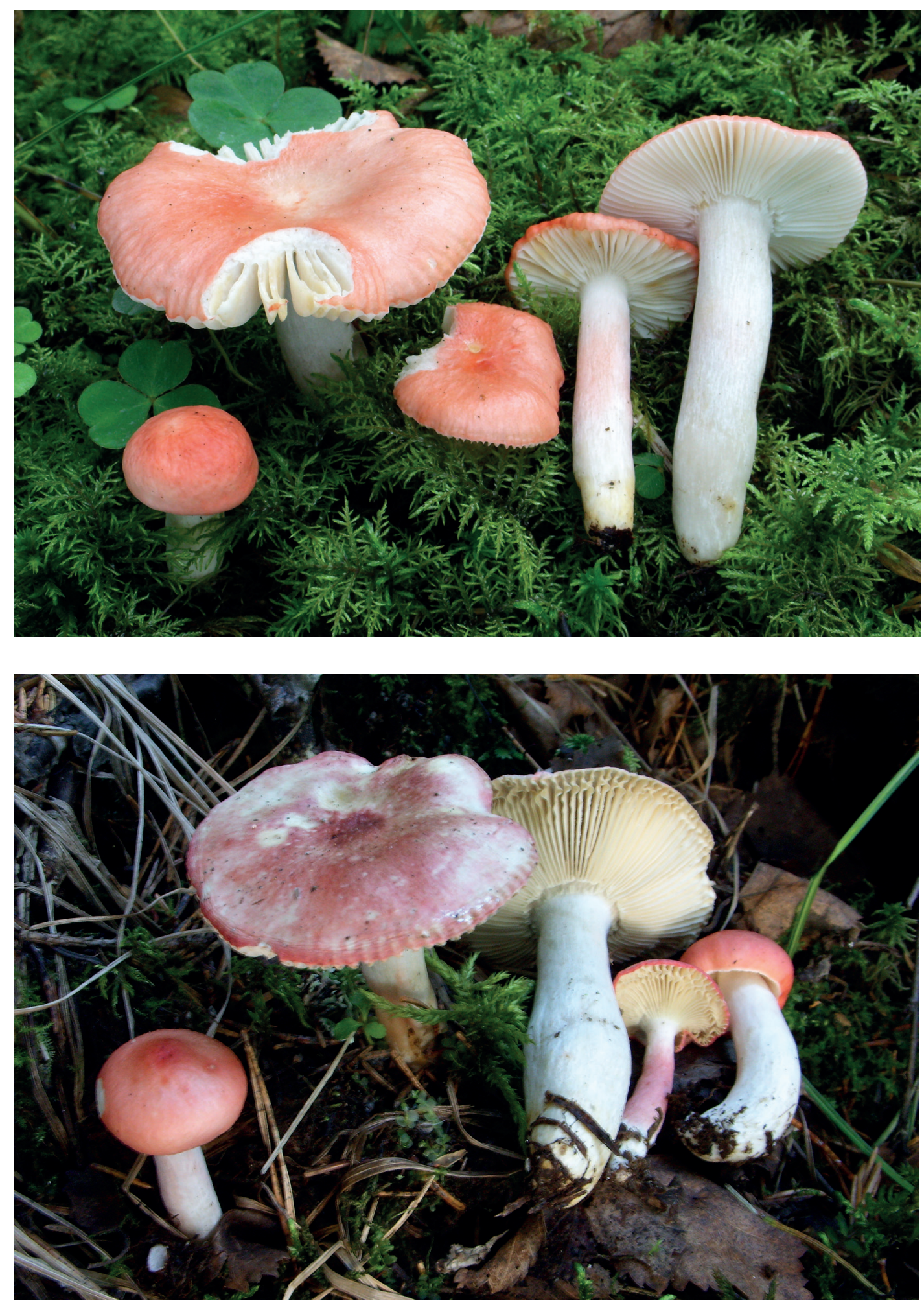


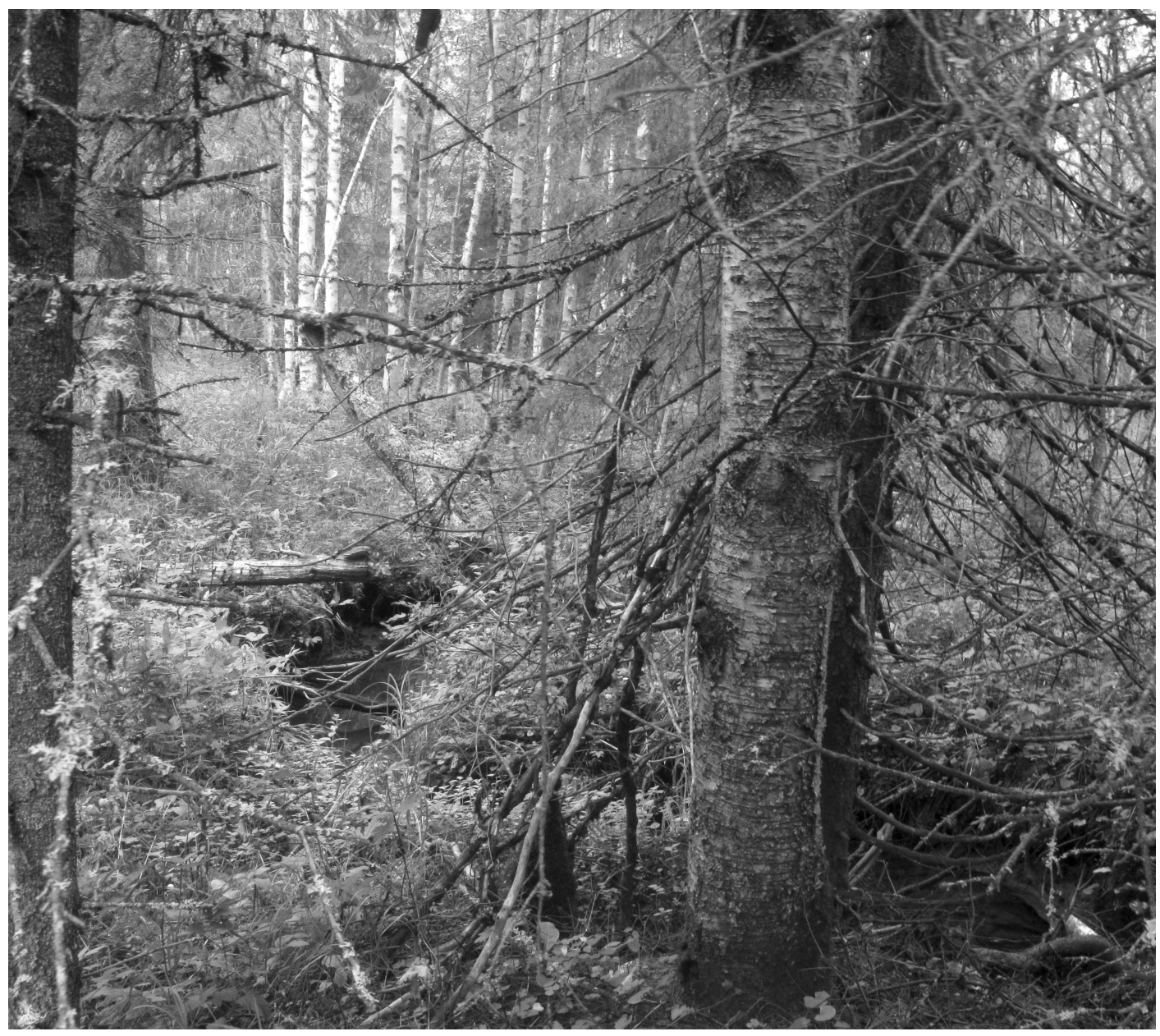

Fig. 1. (left up) Russula pyriodora in situ, Paltamo, Kylmänpuro, 2011 Lahti \& Ruotsalainen (holotype). Photo: J. Ruotsalainen

Fig. 2. (left down) Russula pyriodora in situ, Paltamo, Kylmänpuro, 2010 Ruotsalainen (paratype), somewhat dry fruitbodies. Photo: J. Ruotsalainen

Fig. 3. (right up) Kylmänpuro, habitat of the holotype, 20.VIII.2010. Photo: J. Ruotsalainen 


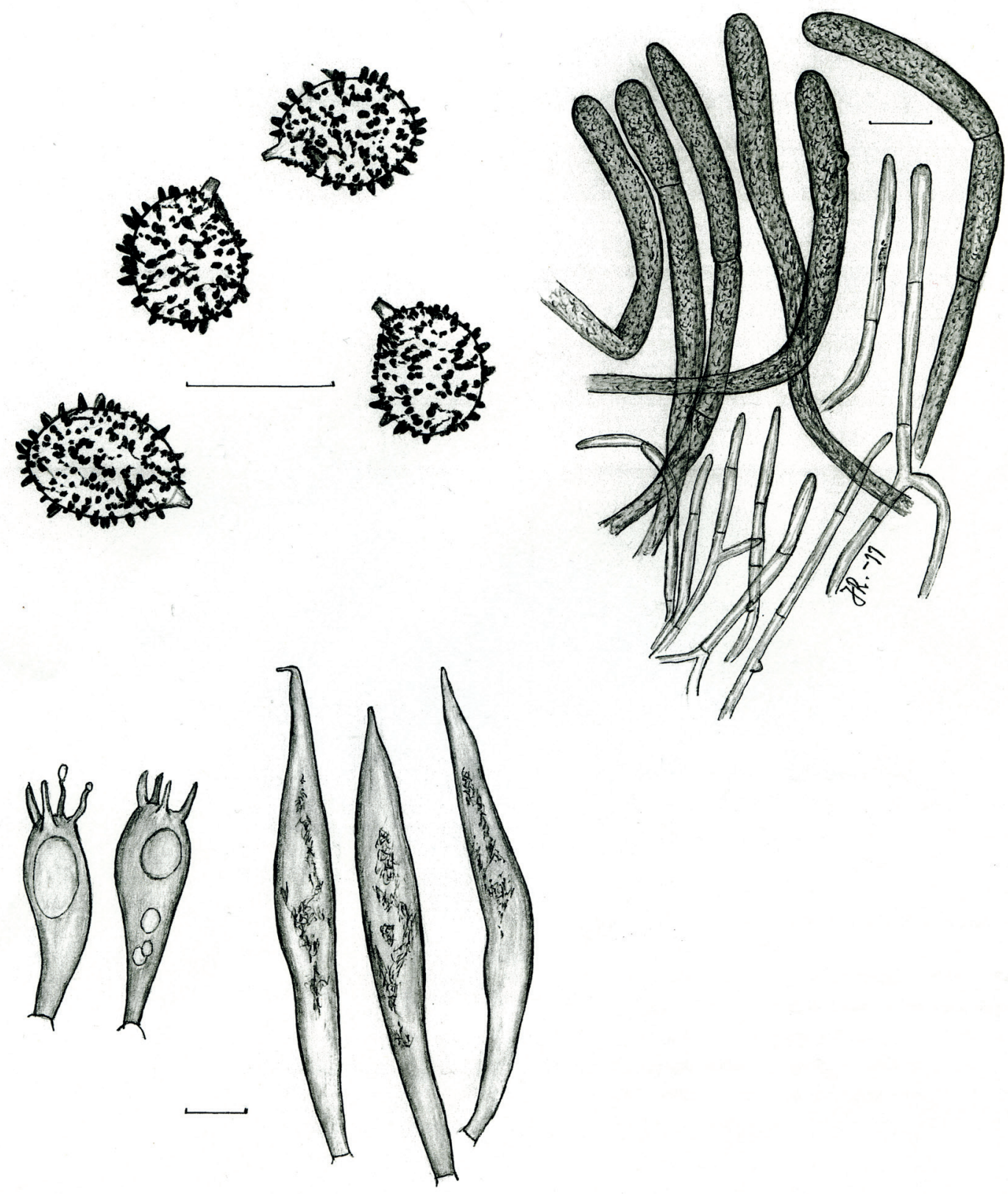

Fig. 4. Russula pyriodora (paratype, Ruotsalainen, JR.8128F). Spores, basidia and elements of the pileipellis. Bars: $10 \mu \mathrm{m}$. 

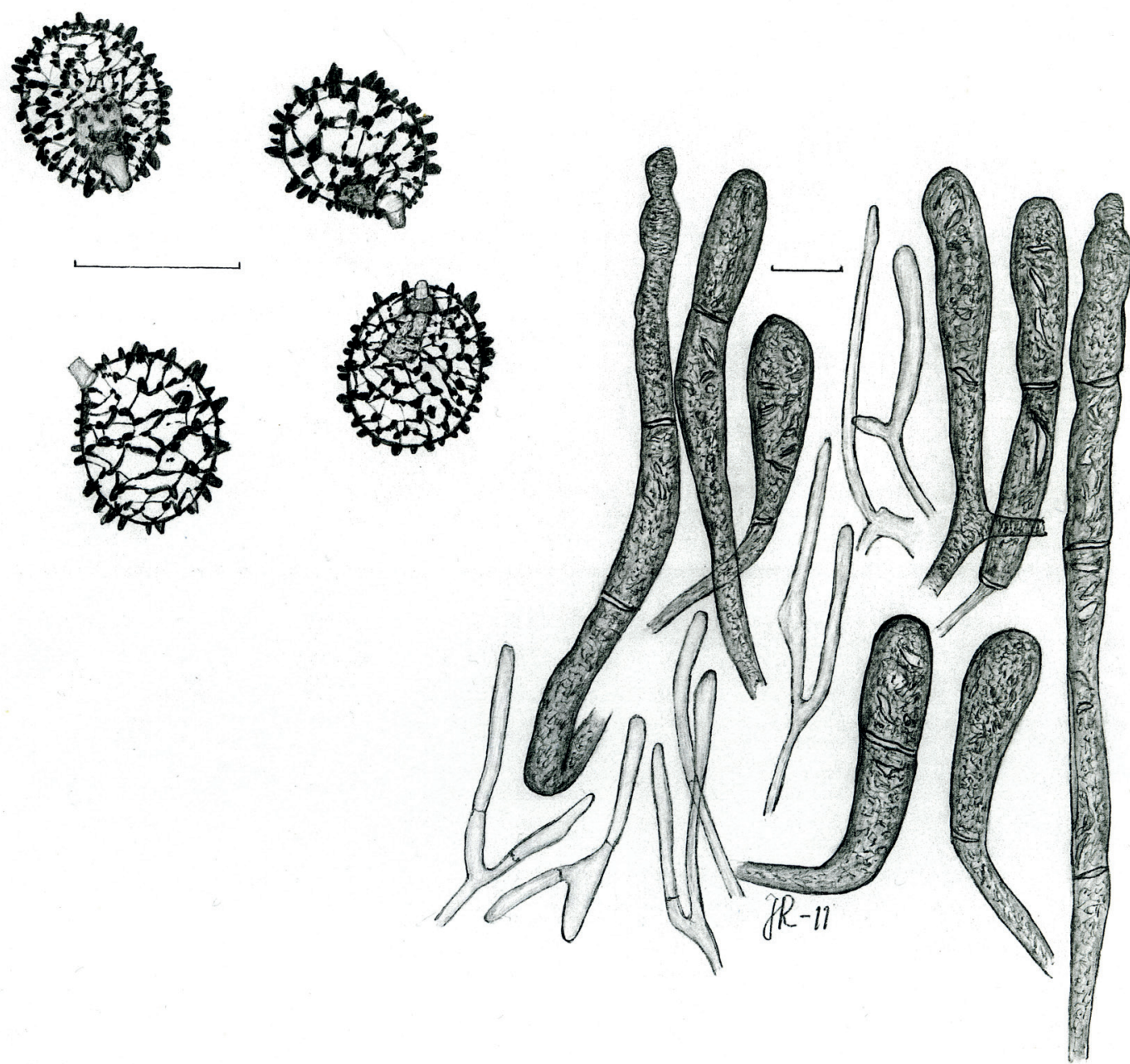

Fig. 5. Russula betularum (Ruotsalainen, JR1394F). Spores and elements of the pileipellis. Bars: $10 \mu \mathrm{m}$. 

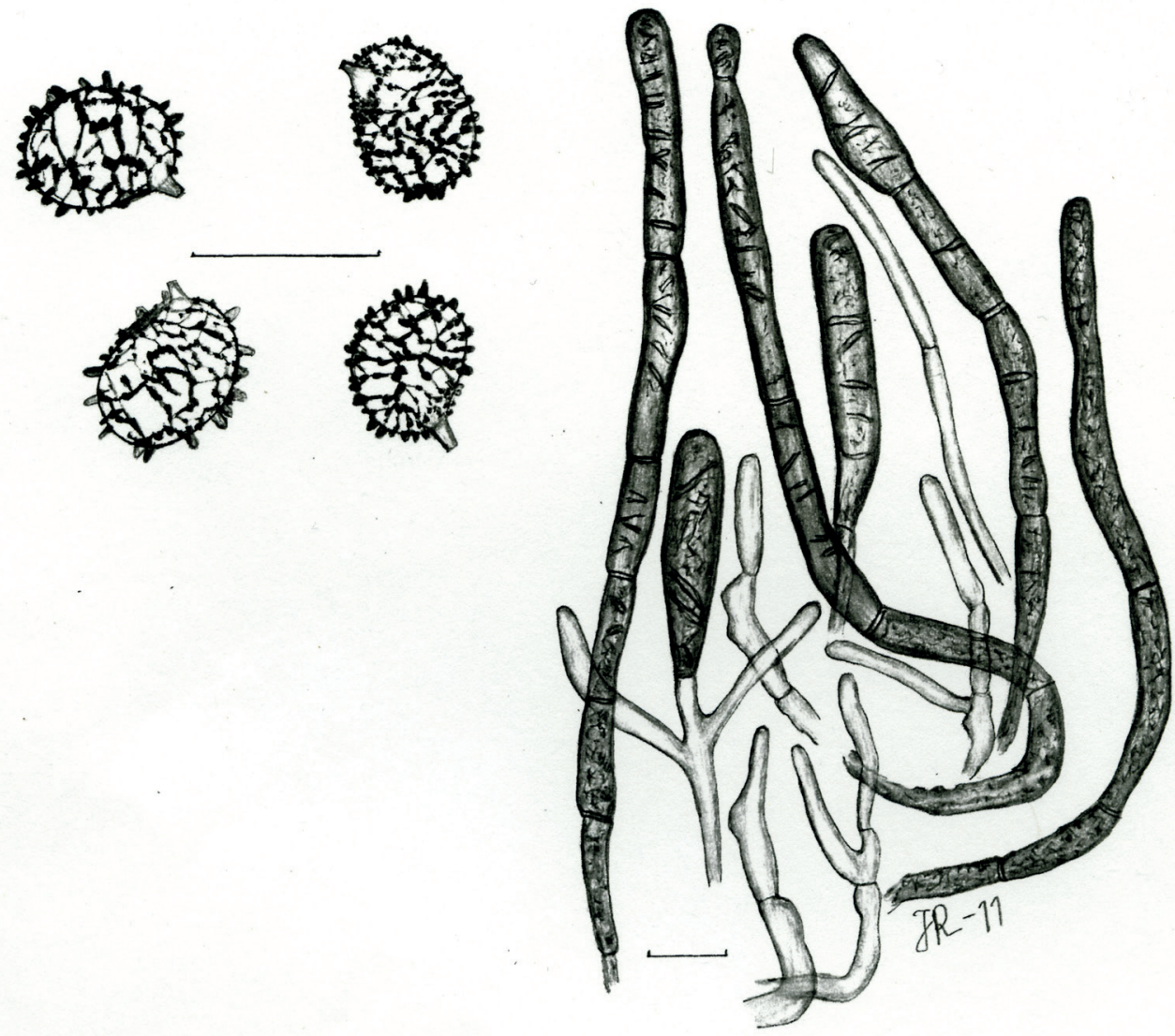

Fig. 6. Russula alborosea (isotype, Reumaux R 63c). Spores and elements of the pileipellis. Bars: $10 \mu \mathrm{m}$.

Acknowledgements: We thank Jukka Vauras for introducing the senior author to the two lush collection sites. Ernest Emmett is thanked for improving the English and Heino Vänskä for helping with one of the last Latin diagnoses.

\section{References}

Hora, F.B. 1960: New check list of British agarics and boleti: Part 4. Validations, new species and critical notes. - Transactions of the British Mycological Society 43: 440-459.

Kärcher, R. 1996: Beitrag zur Kenntnis der Täublinge. Russula-Studien, Teil 3. Was ist Russula elaeodes? - Beiträge zur Kenntnis der Pilze Mitteleuropas 10: 65-78.
Reumaux, P., Bidaud, A. \& Moënne-Loccoz, P. 1996: Russules rares ou méconnues. - 294 pp. Editions de la Fédération Mycologique Dauphiné-Savoie. Marlioz.

Reumaux, P. \& Moënne-Loccoz, P. 2003: Les Russules émétiques: prolégomènes a une monographie des Emeticinae d'Europe et d'Amerique du Nord. - 264 pp. Editions de la Fédération Mycologique DauphinéSavoie.

Romagnesi, H. 1967: Les Russules d'Europe et d'Afrique du Nord. - 998 pp. Bordas.

Sarnari, M. 1998: Monografia illustrata del Genere Russula in Europa. Tomo primo. - 779 pp. Associazione Micologica Bresadola. Trento.

Sarnari, M. 2005: Monografia illustrata del Genere Russula in Europa. Tomo secondo. - 1568 pp. 